\title{
HUBUNGAN KETERAMPILAN PENGELOLAAN KELAS OLEH GURU DENGAN PRESTASI BELAJAR PAK SISWA
}

\author{
Julita Herawati P. \\ Institut Agama Kristen Negeri Tarutung \\ Email: herawatijulita2@gmail.com
}

\begin{abstract}
Abstrak-Tujuan penelitian ini adalah untuk mengetahui hubungan keterampilan pengelolaan kelas oleh guru dengan prestasi belajar PAK. Populasi penelitian 135 orang. Sampel ditentukan secara acak (random sampling) sebesar 25\% dari jumlah populasi yaitu $25 \%$ x 135 orang $=33$ orang. Instrument penelitian berupa angket dan test. Dari uji hipotesa diperoleh $t_{\text {hitung }}>t_{\text {tabel }(\square / 2, n-2)}$ yaitu 4,390 $>2,042$. Maka diketahui terdapat hubungan yang positif dan signifikan antara keterampilan pengelolaan kelas oleh guru PAK dengan prestasi belajar PAK siswa kelas VIII SMP Negeri 2 Muara.
\end{abstract}

\section{Kata Kunci : guru, motivasi belajar}

\section{PENDAHULUAN}

Siswa dalam belajar sangat sering tidak aktif hal ini dikarenakan guru Pendidikan Agama Kristen kurang kreatif dalam melaksanakan pengelolaan kelas dalam proses belajar mengajar. Dalam melaksanakan tugas mengajar, guru tidak hanya menyampaikan materi pembelajaran tetapi juga harus mengetahui kebutuhan siswa agar tercapai proses belajar yang efektif. Dengan demikian guru dituntut untuk melaksakan pengelolaan kelas.Yang penulis amati di lapangan penelitian yaitu di SMP Negeri 2 Muara Kelas VIII, bahwa prestasi belajar PAK siswa sudah mencapai sandard ketuntasan. Dalam kegiatan belajar mengajar, cara belajar siswanya kurang aktif di dalam kelas sehingga kebutuhan belajar siswa banyak yang merasa bosan dan kurang memhami materi yang diajarkan guru. Hal ini guru PAK sudah memperhatikan dalam melaksanakan proses pembelajaran yang tepat dengan keadaan siswanya tersebut. Sesuai dengan profesinya dari seorang guru dituntut adanya keahlian, dengan istilah kompetensi dasar guru. Dalam kompetensi dasar tersebut bagaimana guru mengelola program belajar mengajar untuk mencapai hal tersebut, guru harus mampu menguasai keterampilan mengelola kelas sebagai dasar salah satu aspek penting dalam kompetensi guru. Akan tetapi yang menjadi masalah saat ini, penulis melihat adanya masalah lingkungan tempat penelitian yaitu guru PAK belum dapat menumbuhkan prestasi belajar PAK siswa. Oleh karena itu dalam penelitian ini akan dibahas bagaimana guru sebagai pengelola kelas untuk meningkatkan prestasi belajar PAK siswa. Menurut Sagala (2006:87) bahwa: "Pengelolaan kelas adalah mengatur suasana pembelajaran di kelas, mengkondisikan siswa untuk belajar dan memanfaatkan atau, menggunakan sarana pengajaran serta dapat mengendalikannya, dalam suasana yang menyenangkan untuk mencapai tujuan pelajaran."

Toenli (1992:16) mengemukakan pengelolaan kelas dapat diartikan sebagai usaha guru untuk menciptakan dan mempertahankan kondisi yang memungkinkan kegiatan pengelolaan pengajaran dapat berlangsung dengan dalam adalah suatu proses kegiatan yang dilakukan oleh guru yang bertugas dalam menciptakan, mempertahankan, memelihara keadaan kelas, sehingga setiap individu dapat mengembangkan bakatnya, dan memanfaatkan kemampuannya, supaya kegiatan belajar siswa dalam kelas dapat 
terlaksana serta guru memperhatikan sarana peralatan dan fasilitas di dalam kelas, untuk mencegah gangguan belajar guna menciptakan kondisi belajar yang optimal dan menyenangkan bagi anak didik, sehingga tujuan yang dilakukan oleh guru di dalam suasana kelas yang kondusif dapat mencapai tujuan pengajaran yang hendak dicapai dengan baik". Dalam rangka memperkecil masalah gangguan dalam pengelolaan kelas, maka ada pentingnya mengetahui prinsipprinsip pengelolaan tersebut. Dalam hal ini, Djamarah (2006:187) mengemukakan berbagai prinsip dalam pengelolaan kelas, yaitu: a) Hangat dan Antusias, b) tantangan, c) Bervariasi, d) Keluwesan, e) penekanan dalam hal-hal yang positif, f) Penanaman disiplin, sedangkan komponen keterampilan pengelolaan kelas menurut Iskandar (2009:216) mengemukakan komponenkomponen pengelolaan kelas yaitu: a) Tindakan preventif. Upaya sedini mungkin yang dilakukan oleh guru untuk mencegah terjadinya gangguan dalam pembelajaran.b) Tindakan refresif

Tindakan guru untuk mengatasi, mencari dan yang menemukan solusi yang tepat untuk memecahkan masalah yang terjadi dalam lingkungan pembelajaran.

Sedangkan masalah-masalah dalam pengelolaan kelas Pidarta yang dikutip oleh Djamarah (2006:195) mengemukakan masalah-masalah pengelolaan kelas yang berhubungan dengan perilaku siswa adalah:

1. Kurangnya kesatuan karena adanya kelompok-kelompok dan pertentangan jenis kelamin.

2. Tidak ada standart perilaku dalam bekerja kelompok, misalnya ribut, bercakap-cakap, pergi kesana kemari dan sebagainya.

3. Reaksi negative terhadap anggota kelompok, misalnya rebut, bermusuhan, saling mengucilkan, merendahkan kelompok lain, dan sebagainya.
4. Kelas mentolerasi kekeliruan-kekeliruan temannya yaitu menerima dan mendorong perilaku siswa yang keliru.

5. Mudah mereaksi negati misalnya bila didatangi monitor, tamu-tamu, iklim yang berubah dan lain sebagainya.

6. Moral rendah, pemusuhan,agresif, misalnya dalam lembaga dan fasilitas yang kurang, kekurangan uang dan sebagainya.

7. Tidak mampu menyesuaikan dengan lingkungan yang rendah.

Oleh karena itu perlu diketahui apa yang menjadi Tujuan keterampilan pengelolaan kelas Menurut Arikunto (2002:68): "Tujuan pengelolaan kelas adalah agar setiap anak di kelas dapat bekerja denagan tertib sehingga segera tercapai tujuan pengajaran secara efektif dan efisien". Hal ini berarti bahwa keterampilan pengelolaan kelas bertujuan untuk, membuat setip siswa dalam ruang kelas dapat bekerja, secara tertib supaya tujuan pengajaran itu tercapai secara efektif dan efisien. Dan menurut Djamarah (2002:199) mengemukakan bahwa tujuan pengelolaan kelas adalah "penyediaan fasilitas bagi bermacam-macam kegiatan belajar siswa dalam lingkungan sosial,emosional dan inteletual dan kelas". Berdasarkan pendapat yang dikemukakan di atas, penulis dapat menyimpulkan bahwa tujuan keterampilan guru mengelola kelas adalah untuk menyediakan fasilitas kelas dan mengembangkan kemampuan siswa dalam menggunakan fasilitas, mengembangkan kemampuan siswa menggunakannya, menyediakan kondisi belajar dan bekerja yang baik bagi siswa. Sehingga memperoleh hasil yang baik melalui tercapainya tujuan pengajaran itu.Sehingga setiap anak didik dapat belajar dengan tenang, tertib, dan tidak muncul tingkah laku yang tidak berkenan. Sarana dan fasilitas yang disediakan oleh guru di dalam kelas akan memudahkan pencapaian tujuan pengajaran. 


\section{Guru Sebagai Pengelola}

Guru adalah seorang pengelola di dalam kelas tanpa guru bisa mengelola kelas, suasana kelas akan mempengaruhi jalannya proses belajar mengajar. Menurut Sardiman (2006:169) mengemukakan bahwa: "Untuk mengajar suasana kelas, guru dituntut untuk mampu mengelola kelas, yakni menyediakan kondisi yang kondusif, untuk berlangsungnya proses belajar mengajar". Pengelolaan kelas merupakan keterampilan guru untuk menyediakan atau menciptakan situasi dan kondisi belajar yang kondusif dan menyenangkan yang memungkinkan kegiatan belajar mengajar bisa berjalan dengan baik sesuai perencanaan dan pencapaian tujuan yang dikehendaki. Kondisi yang kondusif dan menyenangkan dapat mewujudkan jiwa guru mampu mengatur suasana belajar, mengkondisikan siswa untuk berguna dan memanfaatkan atau menguraikan sarana pengajaran serta dapat mengendalikan aapabila terjadi gangguan.

\section{Pengelolaan Kelas Yang Tepat}

Menurut Djamarah (2006:179-184) yang perlu dilakukan dalam pengelolaan kelas adalah sebagai berikut:

\section{Pendekatan kekuasaan}

Pengelolaan kelas diartikan sebagai suatu proses untuk mengontrol tingkah laku anak didik. Peranan guru disini adalah untuk menciptakan dan mempertahankan situasi disiplin dalam belajar. Kedisiplinan adalah kekuatan yang menuntut kepada anak didik untuk menaatinya. Didalamnya ada kekuasaan dalam norma yang mengikat untuk ditaati anggota kelas.

\section{Pendekatan ancaman}

Dari pendekatan ancaman ini pengelolaan kelas adalah sebagai suatu proses untuk mengontrol tingkah laku anak didik dilakukan dengan cara memberikan ancaman, misalnya: melarang, ejekan, sindiran, dan memaksa.

\section{Pendekatan Kebebasan}

Pendekatan kelas diartikan suatu proses untuk membantu anak didik agar merasa bebas untuk mengerjakan sesuatu kapan saja dan dimana saja. Peranan guru adalah mengusahakan semaksimal mungkin kebebasan.

\section{Pendekatan Resep}

Pendekatan resep dilakukan dengan memberi satu daftar yang dapat menggambarkan apa yang harus dan apa yang tidak boleh dikerjakan oleh guru dalam mereaksi semua masalah atau situasi yang terjadi di kelas.

\section{Pendekatan Pengajaran}

Pendekatan ini didasarkan atas suatu anggapan bahwa dalam suatu perencanaan dan pelaksanaan akan mencegah munculnya masalah tingkah laku anak didik dan memecahkan masalah itu jika tidak biasa dicegah.

\section{Pendekatan Perubahan Tingkah Laku}

Pengelolaan kelas diartikan sebagai suatu proses untuk mengubah tingkah laku anak didik.Peranan guru adalah mengembangkan tingkah laku anak didik yang baikdan mencegah tingkah laku anak didik yang kurang baik.

7. Pendekatan Suasana Emosi dan

Hubungan Sosial

Pengelolaan kelas merupakan suatu proses menciptakan iklim atau suasana emosional dan hubungan social yang positif dalam kelas.Guru adalah kunci terhadap pembentukan hubungan pribadi itu dan peranannya adalah menciptakan hubungan pribadi yang sehat.

\section{Pendekatan Proses Kelompok}

Peranan guru melalui pendekatan ini adalah mengusahakan agar perkembangan dan pelaksanaan proses kelompok itu efektif.Proses kelompok adalah usaha guru mengelompokkan anak didik ke dalam beberapa kelompok dengan berbagai 
pertimbangan individual sehingga tercipta kelas yang aktif dalam belajar.

9.Pendekatan Elektis atau Pluralistik

Pengelolaan kelas yang berusaha menggunakan berbagai macam pendekatan yang memiliki potensi untuk dapat menciptakan dan mempertahankan suatu kondisi yang memungkinkan proses belajar mengajar berjalan efektif dan efisien.

\section{Prestasi Belajar Pendidikan Agama Kristen}

Pengertian belajar adalah segala hasil usaha yang dilakukan siswa dalam belajarnya, dengan berbagai tingkat keberhasilan.Dari usaha belajar itu diperoleh bentuk-bentuk tingkah laku yang baru yang meliputi pengetahuan,sikap dan keterampilan. Menurut Nasution prestasi belajar Pendidikan Agama Kristen seorang peserta didik dikatakan sempurna jika memenuhi 2 aspek yaitu:

1) Aspek Konitif

Aspek kognitif adalah aspek yang berkaitan dengan kegiataan berfikir. Aspek ini sangat berkaitan erat dengan tingkat inteligensi (IQ) atau kemampuan berfikir peserta didik dalam pembelajaran Pendidikan Agama Kristen.

2) Aspek Afektif

Aspek afetif adalah yang berkaitan dengan nilai dan sikap, Penilaian aspek ini dapat terlihat pada kedisiplinan, sikap hormat terhadap guru, kepatuhan dan lain sebagainya.Aspek afektif berkaitan erat dengan kecerdasan emosi (EQ) peserta didik.

\section{Arti dan Tujuan Pendidikan Agama Kristen}

Menurut Homrighausen dan Enklaar (2008:36):Arti PAK yaitu bahwa dengan menerima pendidikan itu, segala pelajar, muda dan tua, memasuki persekutuan iman yang hidup dengan Tuhan sendiri, dan oleh dan dalam Dia mereka terhisab pula pada persekutuan jemaat-Nya yang mengakui dan memuliakan nama-Nya di segala waktu dan tempat. Selanjutnya Boehlke (2010:501) mengemukakan: Pendidikan Agama Kristen adalah pelayanan dari piahak orangtua dan gereja yang secara khusus melibatkan kaum muda dengan cara yang wajar dalam pengalaman keluaraga Kristen dan kehidupan jemaat tanpa mengharuskan kaum muda itu lebih dulu mengalami pertobatan yang hebat pada umur tertentu. Selain itu Pendidikan Agama Kristen memiliki tujuan tertentu. Sehubungan dengan hal tersebut, Homrighausen dan Enklaar (2008:36) mengemukakan: Tujuan PAK adalah:

a) Memimpin murid selangkah demi selangkah kepada pengenalan yang sempurna mengenai peristiwa-peristiwa yang terdapat dalam Alkitab dan pengajaran-pengajaran yang diberitakan olehnya.

b) Membimbing murid dalam cara menggunakan kebenaran-kebenaran asasi Alkitab itu untuk keselamatan seluruh hidupnya.

c) Mendorong dia mempraktikkan asasasas dasar Alkitab itu, supaya membina suatu perangai Kristen yang kukuh.

d) Menyakinkannya, supaya mengakui bahwa kebenara-kebenaran dan asas-asas itu menunjukkan jalan untuk pemecahan masalah-masalah kesusilaan, sosial dan politik di dunia ini.

\section{Faktor-Faktor yang berhubungan dengan Prestasi Belajar PAK dalam mengelola Kelas}

1. Faktor Internal

Faktor Internal merupakan faktor-faktor yang berasal dari dalam diri siswa tersebut. Faktor ini sangat perlu dalam proses belajar mengajar, dan untuk melatih siswa mandiri dalam belajar, sehingga siswa tersebut memperoleh prestasi yang baik dan memuaskan. Menurut Winkel (1992:24) 
mengemukakan bahwa ada empat faktor internal yaitu:

1) Tahap inteligensi, kemampuan belajar yang diartikan dengan dua cara yakni inteligansi dengan artiyang luas merupakan kemampuan untuk mencapai prestasi, prestasi berfikir main perasaan, sedangkan inteligensi dalam arti sempit merupakan kemampuan akademik yang di dalamnya berfikir dengan perasaan.

2) Memotivasi belajar yakni keseluruhan daya penggerak dalam diri siswa tersebut

3) Persiapan sikap

4) Keadaan fisik menunjukkan pada tahap pertumbuhan kesehatan jasmani.

Berdasarkan faktor yang dikemukakan, maka ditarik kesimpulan bahwa ada empat unsur yang mempengaruhi belajar dalam diri anak. Keempat faktor di atas saling mempengaruhi satu sama lainnya.

\section{Faktor Eksternal}

a) Faktor Lingkungan Keluarga

Siswa yang belajar akan menerima pengaruh dari keluarga bahwa: "Orangtua yang kurang/tidak memperhatikan pendidikan anaknya misalnya acuh tak acuh terhadap belajar anaknya, tidak memperhatikan sama sekali akan kepentingan-kepentingan dan kebutuhan-kebutuhan anaknya dalam belajar, tidak mengatur waktu belajarnya, tidak menyediakan/melengkapi alat belajarnya, tidak memperhatikan anak belajar dan sebagainya, dapat menyebabkan anak didik/kurang berhasil dalam belajarnya".

b. Faktor Lingkungan Sekolah

Hasan (1994:67) bahwa: Seorang guru sebagai pengajar diharapkan menyediakan situasi dan kondisi yang mendukung keberhasilan belajar siswa, guru juga merupakan salah satu faktor yang penting dalam meningkatkan prestasi belajar siswa, sebab gurulah yang mengelola kelas. Dalam hal ini, seorang guru dapat meneladani cara Yesus sebagai Guru Agung. Dalam Mrk 1:22 dikatakan mereka takjub mendengar pengajaran-Nya, sebab Ia mengajar mereka sebagai orang yang berkuasa, tidak seperti ahli-ahli Taurat.

c. Faktor Lingkungan Masyarakat

Masyarakat merupakan faktor yang berhubungan dengan belajar siswa. Menurut Slameto (2003:70) mengemukakan bahwa:Siswa tidak terlepas dari masyarakat, siswa tetap mempunyai kegiatan di dalam masyarakat, teman bergaul bentuk kehidupan masyarakat dan lain sebagainya.

\section{METODE}

Lokasi dan tempat di Desa Muara Kabupaten Tapanuli Utara, Propinsi Sumatera Utara dan penelitian ini dilaksanakan pada Bulan Oktober samapi dengan November 2016.

Dalam penelitian ini yang menjadi populasi adalah semua siswa-siswi kelas VIII SMP Negeri 2 Muara yang berjumlah 135 orang, dan di SMP tersebut keseluruhan siswa beragama Kristen. Dan untuk sampelnya di ambil 25\% jadi diperoleh 33 orang. Intrumen yang dilakukan dalam penelitian ini dengan menggunakan Angket dan Test. Sedangkan untuk uji coba disebarkan kepada responden 10 Orang siswa kelas VIII SMP Negeri 2 Muara yang tidak menjadi responden dengan pertimbangan bahwa siswa tersebut memiliki karakteristik yang sama baik dari segi kemampuan dan karakter siswa. Uji Coba instrument terdiri atas:

a) Uji Coba Validitas Instrumen

Dalam pengujian instrumen instrumen dimaksud untuk menggunakan rumus korelasi Product Moment Pearson yang dikemukakan oleh Arikunto (2002:146) yaitu:

$$
r x y=\frac{N \sum \mathrm{XY}-(\Sigma \mathrm{X})(\Sigma \mathrm{Y})}{\sqrt{\left\{N \Sigma X^{2-}(\Sigma \mathrm{X})^{2} \sqrt{\left\{\mathrm{N} \sum \mathrm{Y}^{2}\right\}}\right.}}
$$

b) Uji Reliabilitas

Reliabilitas adalah indeks yang menunjukkan sejauh mana suatu alat 
pengukur dapat dipercaaya atau dapat diandalkan. Sebelum uji reliabilitas dilakukan perlu dicari lebih dahulu varians setiap butir itemnya dengan menggunakan rumus:

$$
\sigma b^{2}=\frac{\sum X^{2}-\frac{\left(\sum X\right)^{2}}{N}}{N}
$$

Teknik pengumpulan data dalam penelitian ini menggunakan angket tertutup dalam langkah-langkah sebagai berikut:

a. Memberi pengarahan agar mereka dengan jujur menjawab pertanyaan yang ada.

b. Memberi tanda cecklist (V) atau silang (X) untuk setiap jawaban pada item.

c. Mengulkan semua hasil angket dan dicatat ke dalam variabel serta diolah untuk mengetahui kesahan angket.

Dalam pengumpulan data dalam penelitian ini penulis bekerjasama dengan guru bidang studi Pendidikn Agama Kristen.

Untuk mengolah data dan menganalisa data yang telah masuk maka peneliti menggunakan beberapa prosedur analisa yaitu:

1. Mentabulasi jawaban responden setiap variabel, artinya setiap angketyang dijawab disusun serta dijumlahkan menurut options yang telah ditentukan.

2. Mendistribusikan frekuensi jawaban responden dilihat pendestribusiannya berdasarkan hubungan alternatif jawaaban sesuai dengan bobot yang telah ditentukan untuk tiap-tiap alternatif jawaban. Sedangkan untuk menekan nilai dilakukan dengan mengikuti kategori nilai seperti yang dirumuskan Nurkanca (1985:81) yaitu sebagai berikut:

1) 1,00- 1,59 adalah kategori tinggi

2) 1,60 -2,59 adalah kategori kurang

3) 2,60-3,59 adalah kategori baik

4) 3,60-4,60 adalah kategori baik sekali

\section{HASIL DAN PEMBAHASAN}

Nilai rata-rata tertinggi dari ke 22 item yang lain tentang keterampilan pengelolaan kelas oleh guru nomor 12 dengan nilai ratarata 3,79 yaitu guru selalu menegur siswa yang kurang disiplin dalam belajar. Item nomor 13 dengan nilai 3,76 yautu guru selalu memberikan penjelasan tentang jawaban yang sebenarnya dari jawaban yang dikemukakan siswa kepada guru. Sementara item dengan nilai rata-rata terendah dari item nomor 5 dengan nilai rata-rata 1,88 yaitu guru jarang sekali merubah anggota kelompok-kelompok diskusi yang sudah dibentuk. Item nomor 18 dengan nilai rata-rata 2,09 guru jarang sekali menegur peralatan belajar dan fasilitas belajar yang ada di dalam kelas sebelum kegiatan belajar mengajar berlangsung.

diketahui item yang memperoleh nilai tertinggi dari ke-15 item test yang dijawab oleh siswa untuk mengetahui prestasi belajar Pendidikan Agama Kristen adalah item nomor 12 yaitu semua siswa menjawab benar bahwa semua siswa mengetahui bahwa: "Iman timbul dari pendengaran oleh Firman Kristus. Inilah salah satu cara sebagai orang Kristen untuk memberi makan iman kita tetap subur" adalah tertulis dalam Kitab Roma 10:17.

Sementara item yang memperoleh nilai terendah dari item yang lain adalah item nomor 11 bahwa hanya 24 siswa yang menjawab betul bahwa mencuri, merampok, menipu adalah salah satu contoh pekerjaan yang tidak baik dan dilarang Tuhan, karena Allah tidak pernah memberikan talenta yang tidak baik pada manusia. Masih ada siswa yang menjawab bahwa hal itu dipelihara dengan baik. Padahal itu adalah jawaban yang salah.

Dari uji hipotesis dengan menganalisa data dengan uji " $t$ " diperoleh $t_{\text {hitung }}=4,390$. Untuk mengetahui bahwa hipotesa penelitian diterima maka nilai $t_{\text {hitung }}$ dibandingkan dengan nilai $t_{\text {tabel }}$ pada $\square / 2=0,05 / 2=0,025$ dengan derajat kebebasan $n-2=33-2=31$ yaitu 2,042. Dengan demikian $t_{\text {hitung }}>t_{\text {tabel }}=4,390$ $>2,042$. Karena $t_{\text {hitung }}>t_{\text {tabel }}$ maka hipotesa 
penelitian diterima yaitu terdapat hubungan yang positif dan signifikan antara keterampilan pengelolaan kelas oleh guru Pendidikan Agama Kristen dengan prestasi belajar Pendidikan Agama Kristen siswa kelas VIII SMP Negeri 2 Muara Tahun Pembelajaran 2011/2012.

Hasil penelitian ini membuktikan teori yang dikemukakan oleh Usman (1944:8) yang mengemukakan bahwa tujuan pengelolaan kelas yang baik adalah mengembangkan kemampuan siswa dalam menggunakan alat-alat belajar yang memungkinkan siswa bekerja dan belajar serta membantu siswa untuk memperoleh prestasi belajar yang maksimal.

\section{PENUTUP}

\section{Simpulan}

\section{Kesimpulan Berdasarkan Teori}

a) Keterampilan Pengelolaan kelas adalah suatu usaha atau kegiatan guru yang dilakukan setiap memasuki ruangan kelas dengan tujuan untuk mendorong anak didik mengetahui tingkah laku yang sesuai dengan tata tertib kelas. Dengan demikian tercipta interaksi yang menyenangkan antara guru dan anak didik sehingga anak didik termotivasi untuk belajar. Keterampilan Pengelolaan Kelas yang dimiliki oleh guru Pendidikan Agama Kristen meliputi: a) sikap tanggap, b) membagi perhatian, c) pemusatan perhatian kelompok, d) menegur kesalahan, e) memberi penguatan positif dan negatif, f) memperbaiki tingkah laku, g) menemukan dan memecahkan masalah,

h) pengaturan tempat duduk, i) pengaturan alat-alat pengajaran, j) penataan keindahan dan kebersihan kelas.

b) Prestasi belajar Pendidikan Agama Kristen adalah tingkat keberhasilan yang diperoleh oleh siswa setelah mempelajari materi pembelajaran Pendidikan Agama Kristen yang diberikan oleh guru. Hal ini dapat dilihat dari skor hasil test yang dilakukan dalam pembelajaran Pendidikan Agama Kristen.

\section{Kesimpulan Berdasarkan Hasil Penelitian}

Dari hasil penelitian dengan menganalisa data jawaban responden maka diketahui dari uji hipotesa nilai thitung > ttabel $=4,390>2,042$ maka hipotesa penelitian diterima yaitu terdapat hubungan yang positif dan signifikan antara keterampilan pengelolaan kelas oleh guru Pendidikan Agama Kristen dengan prestasi belajar Pendidikan Agama Kristen siswa kelas VIII SMP Negeri 2 Muara Tahun Pembelajaran 2011/2012.

\section{Kesimpulan Akhir}

Berdasarkan teoritis dan hasil penelitian dapat disimpulkan bahwa dengan semakin terampilnya guru Pendidikan Agama Kristen mengelola kelas dengan sikap tanggap, penuh perhatian, memberi petunjuk dengan jelas, memberi teguran, memberi penguatan, memodifikasi tingkah laku siswa, adanya kerjasama dan memulihkan semangat belajar siswa. Hal itu akan membantu siswa untuk belajar dan semakin sungguh-sungguh belajar sehingga mendukung peningkatan prestasi belajar Pendidikan Agama Kristen siswa di sekolah.

\section{Saran}

Sesuai dengan hasil penelitian yang telah dilakukan, dengan ini disarankan kepada:

1) Guru Pendidikan Agama Kristen harus mampu mengelola kelas dengan baik, mengatur tempat duduk siswa supaya rapih, mengatur ruangan kelas supaya bersih dan mengatur tata letak fasilitas belajar supaya tercipta suasana belajar yang bersih, nyaman dan kondusif buat 
siswa dan guru dalam kegiatan belajar mengajar. Dalam meningkatkan prestasi belajar Pendidikan Agama Kristen siswa maka guru Pendidikan Agama Kristen harus mengupayakan upaya diskusi kelompok dengan bergantian anggota kelompok supaya siswa menjalin kerjasama yang baik dengan semua siswa di kelasnya, supaya siswa yang pandai supaya mengajari siswa yang kurang pandai di kelas. Guru Pendidikan Agama Kristen harus memberikan pengajaran yang tepat dan jelas kepada siswa supaya tidak ada lagi siswa yang memperoleh prestasi belajar yang kurang baik di sekolah.

2) Kepada siswa supaya patuh dan taat kepada guru pada saat guru mengatur cara duduk mereka, menyuruh siswa supaya tidak ribut dan memelihara fasilitas belajar di kelas. Siswa harus rajin membaca buku, membaca Alkitab dan rajin mengerjakan tugas supaya siswa mampu memperoleh prestasi belajar Pendidikan Agama Kristen yang bagus.

3) Kepada orangtua siswa supaya menciptakan kondisi rumah yang menyenangkan, nyaman dan kondusif bagi anak mereka untuk belajar dan mengerjakan tugas di rumah. Orangtua siswa harus selalu memberikan dukungan yang baik kepada anak mereka untuk memperoleh prestasi belajar yang baik dengan mengatur jadwal belajar, membuat peraturan di rumah dan menciptakan kondisi rumah yang nyaman untuk belajar.

\section{DAFTAR PUSTAKA}

[1] Arikunto, Suharsimi. (2006). Prosedur Penelitian Suatu Pendekatan Praktik Edisi Revisi VI. Jakarta: Rineka Cipta.

[2] Djamarah, Bahri, Syaiful. (2006). Strategi Belajar Mengajar.. Jakarta: Rineka Cipta.

[3] Homrighausen, E.G dan Enklaar, I.H. (2008). Pendidikan Agama Kristen. Jakarta: BPK Gunung Mulia.

[4] Iskandar, (2009). Psikologi Pendidikan. Jakarta: Gunung Persada Press.

[5] Kartono, Kartini. (1990). Psikologi Umum. Bandung: Mandar Maju.

[6] Lembaga Alkitab Indonesia. Alkitab.

[7] Mulyasa, E. (2009). Menjadi Guru Profesional (Menciptakan Pembelajaran Kreatif dan Menyenangkan). Bandung: PT. Remaja Rosdakarya.

[8] Sanjaya, Wina. (2008). Pembelajaran dalam Implementasi Kurikulum Berbasis Kompetensi. Jakarta: Kencana Prenada Media Group.

[9] Sardiman, A.M. (2005). Interaksi dan Motivasi Belajar Mengajar. Jakarta: Raja Grafindo Persada.

[10] Slameto. (2003). Belajar dan FaktorFaktor Yang Mempengaruhinya. Jakarta: Rineka Cipta.

[11] Sudjana. (2002). Metode Statistika Edisi Revisi VI. Bandung: Tarsito.

[12] Sugiyono. (2010). Metode Penelitian Kuantitatif, Kualitatif dan $R \& D$. Bandung: Alfabeta. 